\title{
The Implementation of Character Education in Social Studies
}

\author{
Fitriani \\ Accounting Education \\ Islamic University of Riau \\ Pekanbaru, Indonesia \\ fitriani@edu.uir.ac.id
}

\author{
Zakir Has \\ Accounting Education \\ Islamic University of Riau \\ Pekanbaru, Indonesia \\ zakirhasyanza@gmail.com
}

\begin{abstract}
This research aims to illustrate the implementation of character education in Social Studies learning. It uses naturalistic qualitative method. It was located at junior high school 4 Rumbio Jaya, Kampar Regency. The subject of this research was a Social Studies teacher. The data collection consisted of observation, documentation, and interview. The data analysis technique in this research used qualitative data analysis procedure such as data collection, data reduction, data presentation, and conclusion/ verification. The result of this study showed that: 1) the teacher has applied character values in Social Studies learning. The values have been attached in the syllabus and lesson plans that are used in the learning process. There were 11 out of 20 characters values applied during the first meeting, while on the second meeting there were 10 values. 2) During the implementation, the characters on the lesson plans and syllabus weren't fully integrated due to the lack of support from the conditions and classroom environment. 3) During the learning process, especially the closing part, the teacher didn't inform the students about the lessons that would be learned for the next meeting. As for the evaluation, the teacher didn't provide a follow-up to the success of learning. 4) Hindrances in implementing character education at school are the limitation of school facilities and infrastructure.
\end{abstract}

Keywords — character education, social studies

\section{INTRODUCTION}

Education is a process of acquiring knowledge that occurs in every human being and there's no end to it. With good education, it can create students who excel in Science and Technology. But unfortunately, along with the advancement of science and technology, the degradation of morals among the youth also occurs. Education has given a huge portion for the cognitive aspect (knowledge) but neglected the development of affective (attitude) and psychomotor (skills) aspects [1].

It can be seen from students that have committed immoral acts, such as cheating, brawling, ditching, even leading to criminal acts. In addition, many teenagers committed free sex and used illegal drugs. According to Badan Narkotika Nasional (BNN), it has reached the number of 5,9 million drug users in 2015. The amount of drug users doesn't only come from adult community, but also younger people who are still in productive age, i.e. students. Other than that, it can be observed from students' behavior that often goes racing while leaving for school, bunking classes, lying, wearing untidy uniforms, and declining manners towards the older people. Based on the problems, it can be concluded that there are students who still do not understand about characters.

The above incidents also occurred at junior high school 4 Rumbio Jaya, Kampar Regency. These misbehaviors showed that the students don't have the characters yet. Therefore, in order to become a great nation, we must act to foster the characters of students. This is clarified by Bung Karno which stated that: This nation must be built by prioritizing character building because it is what will make Indonesia a dignified nation [2]. If it is not done, then the nation of Indonesia will be a coolie.

One solution to solve these problems is by providing character building at school. In addition, the school will have to communicate with parents. The communication aims keep the students' behavior well monitored inside and outside school. So, the success of implementing character education can be evaluated. All levels of education have the same task in shaping the character of their students, nonetheless the students of junior high school. It requires cooperation from all circles. Education policy should take the lead to actualize moral education. Taken together, parents, teachers, and administrators as stakeholders, should join this camp to encourage students to manifest those good values in their lives [3]. All school residents have the same obligation in building students' character, be it school environment, parents, supervisors, headmasters, vice headmasters, teachers, administration staff, school guards, and cafeteria staff.

As one of the character builders at school, teachers must show good examples first. It includes discipline, cooperation, helpful to one another, tolerance, and so on. If the teachers cannot do it themselves, it will be difficult to build students' character. Asides from providing a good example to follow, teachers can insert character values on all subjects. Social Studies is a compulsory subject for junior high school students, including that of junior high school 4 Rumbio Jaya, Kampar Regency. Social Studies subject aims to make students recognize their social environment so that they can adapt to it and has sensitivity and think critically about the events around them. Therefore, Social Studies cannot avoid the task of developing 
morals and ethics. Clarifies that critical thinking is one of the targets of 8 characters strengths [4]. As a subject that studies social environment, the application of character education values is very supportive if integrated into this lesson. Proved that character education contributed to social competence [5]. The application of character education in all levels of education has its own characters. There are 20 characters values to be applied in junior high school. They are as follows:

- Character value in relation to God (religious)

- Character values in relation to oneself: 1) honest, 2) responsible, 3) healthy lifestyle, 4) discipline, 5) hard work, 6) confident, 7) entrepreneurship, 8) logical thinking, critical, creative, and innovative, 9) independent, 10) curious, 11) love knowledge

- Character values in relation to others: 1) aware of the rights and obligations of self and others, 2) obedience to the social rules, 3) respect the work and achievement of others, 4) polite, 5) democratic

- Character value in relation to the environment

- Nationalism values: 1) nationalist, 2) respecting diversity

Integrating characters into Social Studies learning needs preparation for the subject to be suitable to the characters that will be applied. Preparation consists of three stages: planning, implementation, and evaluation.

Planning is a stage that must be prepared by teachers because at this stage they need to modify the syllabus, lesson plans, and learning materials to support the implementation. Teaching and learning activities consists of pre-activity, whilst activity, and post activity. This activity was conducted so that students will practice characters that have been incorporated into the syllabus and lessons plans. The last one is evaluation.

Seeing the complexity of teachers' role in carrying out their duties to shape students' character in learning, the researcher limits the scope of this study on the implementation stage where the learning process takes place. The purpose of the study is to acquire information related to the implementation of character education in Social Studies education at junior high school 4 Rumbio Jaya, Kampar Regency.

\section{LITERATURE REVIEW}

\section{A. Implementation}

Every plan to achieve educational goals requires implementation. Described implementation as to implement or to apply [6]. In education, a curriculum has been designed to be fully implemented. Educational planning that's not supported by an organized system and actions to implement will be pointless. Therefore, the implementation of education expects planning and it should be relevant. Pressman and Wildavsky [6] suggested that implementation means to carry out, accomplish, fulfill, produce, complete. Based on the experts' statements, it can be concluded that implementation is a series of activities from ideas that are planned and have been arranged to achieve the objectives. The plan should be performed by identifying needs, formulating vision, formulating missions, and defining programs [7]. Good planning will guide to good implementation of the character education [8].

\section{B. Character education}

The behavior of every human being is different. A person's behavior shown in everyday life can form a habit that will develop into a character due to the continuous acts. Character education can be interpreted as a deliberate desire to develop ethical values and personality for adolescents [9]. Simple character education (attempting to build character both in and outside of class one trait at a time by emphasizing good behavior) [10]. As a deliberate desire, teachers need to prepare and make plans for which characters will be applied to the students. Implementing it in the classroom consists of teaching, training, and being a good role model [11]. Developing students' character also requires changing school culture [12]. The method must be tailored to the condition of learners. The atmosphere of the teaching and learning process in the morning will be different if done in the afternoon. Consequently, teachers should be able to use the right method so the character building can be established well. A fun learning environment makes students more focused and easier to be directed. [13] Also defines character education as a deliberate implementation that governs behavior based on human values. It aims to train individuals to become academically successful.

\section{Social Studies Learning}

The subjects given in schools are very diverse, it aims that students have basic insight into various fields of education and will be useful if entering the next level of education. They include Science, Social Studies, Indonesian Language, Mathematics, Pancasila education, etc. One of the subjects given at junior high school is social studies. Social studies are an integration of various branches of social sciences such as sociology, history, geography, economics, politics, law and culture [14].

Social studies examine a variety of sciences that fall within the scope of social science. Wiyono [15] suggests that it is a subject that studies humans in all aspects of life and their interactions in society. By studying social studies at school, students are expected to know interrelated concepts in the social sciences. Basically, social science is intended for human life which involves all its behavior and needs.

Characteristics are distinctive parts of a subject. These characteristics distinguish each subject from other subjects. Besides having characteristics, social studies learning also has a basic concept. The basic concepts of social studies consist of: 1) interaction, 2) 
interdependence, 3) continuity and change, 4) diversity/similarity/difference, 5) conflict and consensus, 6) pattern, 7) place, 8) power, 9) trustworthiness, 10) justice and equity, 11) scarcity, 12) specificity, 13) culture, 14) nationalism [16]. Looking at some basic concepts that have been mentioned, social studies are a complex and complete learning. The values of nationalism are very important to be implemented in the present life as the foundation for establishing the national characters [17].

\section{RESEARCH METHOD}

The type of research is a naturalistic qualitative research that interprets the phenomenon encountered in the field and no manipulation in its processing. This study interacts with the subject, so the data was obtained from an authentic and natural phenomenon. It was located at junior high school 4 Rumbio Jaya, Kampar Regency. It started from January until March 2017. The subject of this research was determined by using purposive sampling technique. This technique is based on certain considerations. The subject of this research was a Social Studies teacher at junior high school 4 Rumbio Jaya, Kampar Regency.

The data collection uses several techniques that are observation, interview, and documentation. In qualitative research, the researcher is the main instrument to collect the information. In collecting the data, the researcher made interview and observation guides tailored to the table of specification for interview and observation. For observation, the researcher divided it into three stages: pre activity, whilst activity, and post activity. The observation result that doesn't correlate with the observation guide will be used as a reference for the interview. Therefore, it will also be used as the researcher's interview guide.

The source of the research data consists of primary and secondary data. The primary data is obtained directly from the respondents through interview. In this study the respondent was a Social Studies teacher at junior high school 4 Rumbio Jaya, Kampar Regency. Secondary data is taken from documents required for the research, e.g. lesson plans, syllabus, and students' evaluation sheet. For the data analysis technique, the researcher refers to the Miles and Huberman's model [18], such as data reduction, data presentation, and conclusion/verification.

\section{FINDINGS AND DISCUSSION}

\section{A. Description of research finding}

This study was conducted to observe the learning process by a Social Studies teacher, Mr. Usman, created the syllabus and lesson plans. He also incorporated the characters, namely discipline, caring, respecting others' opinion, responsibility, entrepreneurship, and confidence. The process of Social Studies learning was divided into three stages; pre activity, whilst activity, and post activity. [19]
Mentioned that there are three important elements in character education such as principles, process, and practice in learning.

Character education in learning has been implemented by the teacher since he compiled the lesson plans. Based on the interview with the teacher, the lesson plans have been created at the beginning of each semester. It relates to Standard Competence (SK) and Basic Competence (KD) contained in the curriculum and syllabus. From the document analysis, it was found that he had attached the characters into the syllabus and lesson plans for his teaching references. In the lesson plan, the characters to be taught are discipline, caring, respecting others' opinion, responsibility, entrepreneurship, and confidence. This is clarified by [20] that the characters are integrated in the lesson plan and syllabus by the teacher. They are selected and adjusted to SK/KD and the learning objectives. The teacher also associated it with learning methods that will be used including the implementation of character education. The lesson plan explicitly included the character values.

Based on the observation in the classroom during the teaching and learning process, the finding of the research can be described as follows:

\section{Pre-Activity}

During the observation on February $1^{\text {st }}, 2017$, the researcher found that the teacher arrived in the classroom on time and greeted the students. Before starting the lessons, the chairman led the students to pray together. Next, the teacher checked the students' attendance and asked why certain students didn't come and told students to recite some verses of the Qur'an by taking turns. In addition, the teacher prepared the students to involve in the learning process. The teacher asked some questions regarding the next lesson that is about Indonesia's economy. Some students dared to express their opinions. After they responded, the teacher explained the learning objective and the upcoming materials.

The finding showed that the teacher integrated the characters in the pre-activity such as discipline, wellbehaved, religious, caring, and expressing opinions. The interview also clarified that the teacher has tried to follow each step in the lesson plan. The characters have been added so the learning objective can be achieved.

During the observation on February 8th, 2017, the teacher arrived 15 minutes later than the schedule. The teacher greeted and conditioned the readiness of the students, invited the students to pray before starting the lessons, checked their attendance, and warned those who came late. Subsequently, the teacher asked one student to recite the Qur'an and motivated them to study.

According to the researcher's observation during the second meeting, the teacher has added some 
characters such as well-behaved, religious, and caring. Furthermore, the teacher didn't give a question about the previous material nor the next one because he was late. Consequently, he didn't explain the upcoming material so the time allocation could be reached.

In the first and second meeting, the teacher didn't inform the students about the character values to be applied. As said by the teacher, sometimes told the students directly and sometimes he didn't.

\section{Whilst activity}

In Standard Competence about understanding Indonesia's economic activities, the meeting was split into two times. For the main activity, the teacher performed the following steps:

In the first meeting, the learning process was done by implementing group task and discussion. On February $1^{\text {st }}, 2017$, the character application during this activity was to give the students a chance to express their ideas and opinions respectively. The activity was described as follows:

a. The teacher told the students to read the material

b. The teacher asked the students to give their own opinions regarding the material

c. The teacher explained the material

d. For the teacher and students to interact, they held a question and answer session to make the class more active and train students' skills

e. The students were divided into 5 separate groups consisting of 5-6 people

f. Each group was given different materials and started discussing.

g. The teacher led the discussion

h. Each group was asked to present their discussion in front of the class and rotated the groups

i. The groups that weren't presenting had to listen and prepared a question.

In this meeting, the teacher confirmed the students' understanding about the materials as presented by their classmates. Then, the teacher reinforced students' knowledge by giving additional information. In addition, the teacher motivated the students who weren't good enough in presenting to improve themselves.

Through the implementation of learning in the first meeting, it was found that Social Studies learning instilled the character values for the students. Characters include literacy (love for reading) and curiosity, cooperation, responsibility, respecting others' opinions, confidence, and critical thinking.

In the second meeting on February $8^{\text {th }}, 2017$, the steps following the learning activity are described such as:

a. The teacher explained the material

b. The students were given a chance to summarize the material which they had discussed c. The teacher and students conducted Q\&A session about the material which they didn't understand

d. The teacher divided students into 2 groups, 14 students got the questions and 14 other students got the answers

e. The students matched the questions with the right answers on their classmates' answer sheets.

f. The students took turns to provide the matched questions and answers in front of the class.

The finding during the observation during the second meeting showed that the teacher gave an instruction and explanation about the answers from the students. If the questions didn't match the answers, the answer would be exchanged with the right one. From the observation result, the characters are responsibility, independence, curiosity, confidence, and critical. Both first and second meeting were conducted inside the classroom because there were no supporting facilities to do it outside the classroom.

\section{Post activity}

During the first meeting on February $1^{\text {st }}, 2017$, the teacher asked the students to conclude the lesson. $\mathrm{He}$ eventually closed it by praying and greeting in this meeting, the teacher didn't conduct an assessment through the test. Based on the interview, the teacher that he had assessed the students indirectly by observing how the students discussed and presented the result of their discussion, so the teacher felt that written test was unnecessary at this point.

On February $8^{\text {th }}, 2017$, the teacher asked one of the students to draw a conclusion from the given material. The teacher also gave a quiz to the students. Before doing the quiz, the teacher reminded the students to use their own abilities and warned that cheating was prohibited. After all the students finished their task, the teacher gave motivation to keep up the spirit for learning. The teacher closed the lessons with a greeting. The values instilled in this activity contain religious, honest, and confident values. In this activity, the teacher did not deliver the upcoming material for the next meeting. In the interview, the teacher stated that students already knew the material to be studied from the textbook, so he didn't feel the need to inform it again at the end of the lesson.

\section{DISCUSSION}

Character education is intended as well as character building. It is a long process of instilling noble values, character, and nationality. Thus, all teachers as educators are strongly required to instill the values in each lesson. Integrating character education in learning can raise students' awareness to apply it in daily life. Awareness of character values will change students' attitudes and behavior for the better. Therefore, character education and school culture also need to be developed based on wisdom [21].

The implementation of character education starts from planning, implementing, and learning evaluation. 
The principles of contextual learning can be adopted in making learning plans (designing learning activities and assessments in syllabi, lesson plans, and teaching materials), carrying out learning and evaluation processes [22].

The role of school that fosters moral society needs to focus on moral development and character education [23]. It can be done in the class. The success of the learning process in the classroom is determined by the mastery of the subject matter and the ability of teachers in teaching, so that the students can understand what is delivered by the teacher. Implementation of character education in Social Studies learning at junior high school 4 Rumbio Jaya has been conducted on pre activities, whilst activities and post activities.

During the pre-activity, the teacher has applied the characters. One of them is religious character. The teacher always opened and closed the lesson with a greeting. The teacher also invited the students to pray and give thanks to God. The value of the religious character is a characteristic value of attitudes and behaviors that adhere to the implementation of religious teachings, tolerant of other religious practices, and living in harmony with the followers of other religions [24]. In addition, in the pre activities the character of mutual care was also included by inquiring about the students who were absent.

The implementation of character education in Social Studies on pre-activities was adapted to the lesson plans, syllabus, and textbooks. [25] Suggested that the implementation of character education in learning activities can be done by providing learning materials, implementing learning methods, and encouraging students to be active. The methods used in character education are lecture, discussion, question and answer and make-a-match methods. Through the methods used by teachers, students are required to be more active in learning. In accordance [26] an effective character educator always looks for the connection between academic content and character qualities to be developed.

In exploratory activities, the teacher invited students to do a question and answer method on current issues related to learning materials. In addition, the teacher stimulated students to always dare to ask if there was a material that was less understood or known. The teacher always invited students to always be diligent in reading the material. Literacy means a habit that makes time to read the materials to get the good benefits [24]. Character education in the classroom was implemented with multiple character values. It was shown by the students' attitudes during the learning process of Social Studies lessons. Students created a group discussion with full responsibility and had the ability to work together to complete the tasks assigned by the teacher and participated actively in the learning process.
Similarly, while using make-a-match method, students can work with each other in finding the right questions and answers. Students were also encouraged so that they dared to show up in front of the class and gave their ideas.

In closing activities, the characters applied were religious and confident. The students were invited to infer the material that has been studied. In addition, the teacher also tried to establish honest characters and tried their best in performing the tasks at the end of the lesson. As described [27], good individuals always try to do the best.

During the observations for this study, the researcher found that 5 characters values listed in the lesson plan has been implemented during the teaching process. The character of discipline was applied when the teacher came to the class on time, it also applied to the students so that no one was late to the class. The character of caring was applied when the teacher asked why students were absent from school. Appreciating others' opinion was implemented during the discussion. The character of responsibility was applied when the students created study groups and presented the results of their discussions. The character of confident applied when the teacher provided the opportunities for students to conclude the material that has been studied. Lastly, the character of entrepreneurship did not appear in the learning process.

In addition to the five characters above, the teacher has also indirectly implemented the value of other characters. Of the 20 characters for junior high school [24], there were 11 characters, namely religious, polite, disciplined, caring, love for reading, curiosity, cooperation, responsibility, confident, and critical thinking. While in the second meeting they amounted to 10 , such as religious, polite, caring, responsibility, independent, curiosity, cooperation, confidence, responsibility and critical.

The teacher explained that not all the character values are implemented simultaneously in a single meeting. The results of the previous study by Yuniardi also showed that in the implementation of Social Studies learning at junior high school PGRI Ciputat there were 12 out of 18-character values applied [28]. It shows that the application of character education in learning needs to be conceptualized at every meeting so that all character values can be implemented. Similarly, a study by Berkowitz and Bier [29] explains that effective character education requires professional policies, strategies of pedagogical ability, examples of role models, classroom management strategies and instructional services.

Character values that are implemented in Social Studies at junior high school 4 Rumbio Jaya Kampar focused on the values listed in the lesson plans. The values were tailored to the learning materials to be delivered and associated with the methods and 
approaches used. The value of the previously implemented character was also selected and adapted to the competencies and learning objectives.

Based on the findings of this study, the implementation of character education in Social Studies learning has been applied at junior high school 4 Rumbio Jaya, Kampar Regency. This is in line with the government regulation that the stages of learning activities consist of pre-activity, whilst activity, and post activity. They are implemented so that learners can practice the aimed character values. It's just that in the learning process, especially the post-activity, the teacher did not deliver the lesson plans/materials to be learned for the next meeting. Likewise, in the evaluation, the teacher did not always provide a follow-up to the success of learning. The most teaching and assessment in higher education focus on cogitative skills of knowledge and understanding rather than on affective outcomes of values, attitudes and behaviors [30].

The implementation of character education has indeed been applied in Social Studies learning at junior high school 4 Rumbio Jaya. However, it does not mean that there are no obstacles or hindrances that teachers encountered in implementing character education during the learning process.

Based on the observation, document analysis and interviews conducted, a mismatch was discovered. The character values listed in the lesson plans are sometimes not found during the lessons. On the contrary, the character values found during the observation were not listed. Based on the theory of Amri, basic character values can be developed to be more or higher in accordance with the needs, conditions and school environment. It is reasonable if the expectation doesn't meet the reality in order to adjust to the conditions [25]. However, we should be able to find the source of the problem.

The problem of not finding the actual character values listed in the lesson plans during the observation or vice versa, i.e. the teacher cannot implement the value of certain characters contained in the lesson plans because of the condition of the students as well as nonsupportive classroom environment. In addition, the obstacles found in the implementation of character education in junior high school 4 Rumbio Jaya were limited facilities and infrastructure that support the learning and teaching process. This is in line with the finding of Putri's research that the development and the inculcation of character education values is done through the available facilities such as places of worship, laboratory, and supported by various extracurricular programs [31]. Incomplete facilities and infrastructure also include limited space for the computer laboratory. The school library still lacks the collection of books. School facilities are still simple, and the study space is also limited. The other obstacle is that not all teachers are able to assist students' character-building activities. Therefore, good coordination and cooperation are needed from every resident of the school.

\section{CONCLUSION}

Based on the results of research that has been done, it can be concluded that the Social Studies teacher in junior high school 4 Rumbio Jaya has applied the values of character education in Social Studies subject. Character education is implemented in learning but hasn't reached the target yet. From the research finding in the implementation of character education on Social Studies learning, not all elements of characters were applied.

Factors inhibiting the application of character education in junior high school 4 Rumbio Jaya Kampar Regency are the lack of available facilities and infrastructure in schools, so the process of learning implementation is less than optimum. Based on the conclusion of the research, the researcher can give suggestions as follows:

First, for schools: a) Provide regular evaluation in guiding teachers during the application of character education. b) Provide information on the progress of students' behavior change to parents, either through formal or informal meetings. c) Facilitate teachers to develop models of character education in general and on social studies and facilitate trainings that can develop teachers' creativity in character development.

Second, for teachers: a) Update learning tools in each semester. It is intended that the short comings and weaknesses implemented in previous learning can be improved. b) Include the character values to be applied in each lesson. c) Tell the students about the characters to be achieved in each lesson. d) Make an evaluation of character change assessment of each student.

Third, the students are expected to consistently apply the values of the characters that have been obtained both within the school environment and outside the school environment.

Fourth, for the next researcher: a) Increase the observation time during the research, so that the conclusion can be better. b) Conduct a research on evaluation of character education assessment.

\section{REFERENCES}

[1] Wiyani. Save our children from school bullying. Yogyakarta: Ar-Ruzz Media, 2012.

[2] Samani, Muchlas \& Hariyanto. The concept and model of education character. Bandung: Remaja Rosdakarya, 2012.

[3] Agboola, A., Tsai, K.C. Bring character education into classroom. European journal of educational research, 2012.

[4] Lickona, T., \& Davidson, M. Smart and good high schools. Cortland: centre for the $4^{\text {th }}$ and $5^{\text {th }} \mathrm{Rs}, 2005$.

[5] Cheung, Chau-Kiu., \& Lee, Tak-Yan. Improving social competence through character education. Journal Evaluation and Program Planning, Vol 33, 2009, pp. 255-263.

[6] Nurdin, Syafruddin. Professional teacher and curriculum implementation. Padang: Quantum Teaching, 2005. 
[7] Hill, E. Milliken, T., Goff, J \& Clark. Promoting character and resiliency among elementary school students: an assessment of the care now Program. Journal of youth development. 10 (1), 2015, pp. 95-105.

[8] S. Jacques S. Benninga., Marvin W. Berkowitz., Phhllis, Kuehn., Karen, Smith. The relationship of character education implementation and academic achievement in elementary school. JR. CE. 1 (1), 19, 2003.

[9] Lickona, Schaps \& Lewis. Eleven principles of effective character education. In J. L. De vitis \& T. Yu (Eds), Character and moral education, New York: Peter Lang, 2011, Pp. 30-35.

[10] Davis, M. What's wrong with character education? American journal of education, 2003.

[11] Elias, Maurice. Character education: better students, better people. Education Digest, 75(7), 2010, pp. 47-49.

[12] Shield, David Light. Character as the Aim of education. Phi Delta Kappan, V 92 (8), 2011, pp. 48-53.

[13] Katilmis, A., Eksi, H., \& Ozturk, C. Efficiency of social studies integrated character education program. Educational sciences: theory and practice, 11 (2), 2011, pp. 854-859.

[14] Trianto. Integrated learning model. Jakarta: Bumi Aksara, 2010.

[15] Tasrif. Introduction to education sosial studies. Yogyakarta: Genta Press, 2008.

[16] Solihatin, Etin., \& Raharjo. Cooperative learning. Analysis of social studies learning models. Jakarta: Bumi Aksara, 2009.

[17] Kulap, M., Warto, M., Joebagio, H. Nationalism of Nani Wartabone; Nation character building foundation of Indonesia. International Journal of Multicultural and Multireligious Understanding, 43, 2017, pp. 12-21.

[18] M. A. Miles. Inqualitative data analysis; an expanded sourcebook, 1994, pp 50-72.

[19] Elmubarok, Zaim. Grounding value education, gathering scattered, connecting disconnected, and uniting the scattered. Bandung: Alfabeta, 2008.
[20] Wibowo, Agus. Character based literacy education. Yogyakarta: Pustaka Pelajar, 2012.

[21] Suyitno, Imam. Development of character education and culture for understanding local wisdom. Jurnal pendidikan karakter, UNY. 2 (1), 2012, pp. 1-1.

[22] Rusydiyah, Fatimur., et al. Learning plan. Surabaya: Amanah Pustaka, 2009.

[23] Althof, W., \& Berkowitz, MW. Moral education and character education: their relationship and roles in citizenship education. Journal of moral education, 35 (4), 2006, pp. 495518.

[24] Kemdiknas. Character education in junior high school. Jakarta: Direktorat PSMP, 2010.

[25] Amri, Sofan dkk. The implementation character education in learning. Jakarta: Prestasi Pustakarya, 2011.

[26] Zuchdi, Darmiyati. Character education in the perspectif of theory and practice. Yogyakarta: UNY Perss, 2011

[27] Battistich, Victor. Character education, prevention, and positif youth development. Illinois: University of Missouri, St Louis, 2007.

[28] Yuniardi. Diah. The implementation character education in social studies at SMP PGRI Ciputat. Universitas Islam Negeri Syarif Hidayatullah. Jakarta, 2015.

[29] Berkowizth, Marvin W., \& Bier, Melinda C. What works in character education? Journal of research in character education, 5 (1), 2007, pp. 29-48.

[30] Shephard, K. Higher education for suitability: seeking affective e learning outcomes. Journal sustainability in higher education, 2008

[31] Putri, Noviani Achmad. The inculcation of character education values through sociology subjects. Jurnal komunitas, Vol 3 (2), 2011, pp. 205-215. 